\title{
Proposal of Blended Orientation of Scientific Works by Comparison Face-to-Face and Online Processes
}

\author{
Pollyana Notargiacomo Mustaro \\ Mackenzie Presbyterian University, São Paulo, Brazil
}

\section{polly@mackenzie.br}

\begin{abstract}
The execution of academic researches - such as Undergraduate work, Master's or PhD Thesis - is often supervised by a research advisor. The development process of such works could be characterized as face-to-face, remote or blended orientation, which combines both of former ones. The construction of a proposal for blended academic orientation involves mapping and analysis of elements, as well as didactical and communication structures that would differs face-to-face meetings from virtual interactions. The paper presents some considerations about relevant characteristics related to digital generation and learning theories that value interaction in order to built knowledge, thus allowing the determination of a blended methodology that aims to enhance intrinsic motivation and investigative posture of students at any level.
\end{abstract}

Keywords: blended orientation, face-to-face orientation, online orientation, advisor-advisee relationship, digital communication tools.

\section{Introduction}

The accelerated rhythm of nowadays' technical-scientific trends institutes a knowledge-flow (Lévy, 2001) that demands the construction of personal learning paths (Lévy, 1997). The development of abilities that allow adaptation of individuals to such constant and increasing transformations of contemporary context requires people to insert research and projects as integrant elements of educational routine.

In this direction, one of the initiatives currently instituted in undergraduate courses is the development of Undergraduate Work (UW). This is based on magnification and/or exploration of knowledge areas related to undergraduate studies, which collaborates to the professional growth of students when trying to develop a reflexive and investigative position before a wide variety of phenomena and problems.

In a complementary way, Master's and $\mathrm{PhD}$ programs constitute a specific locus to establish in-

Material published as part of this publication, either on-line or in print, is copyrighted by the Informing Science Institute. Permission to make digital or paper copy of part or all of these works for personal or classroom use is granted without fee provided that the copies are not made or distributed for profit or commercial advantage AND that copies 1) bear this notice in full and 2) give the full citation on the first page. It is permissible to abstract these works so long as credit is given. To copy in all other cases or to republish or to post on a server or to redistribute to lists requires specific permission and payment of a fee. Contact Publisher@InformingScience.org to request redistribution permission. dependent researchers. The expressive increase of these programs in a developing country like Brazil $-5.6 \%$ per year in from 1976 to 2004 ("National Plan of Post-Graduation", 2004) -, and in U.S.A. - with growing projection of $35 \%$ in Master's and 19\% in PhD degrees from years 2002-2003 to 20132014 (Hussar, 2005) -, configure possi- 
bilities and conducts of consolidated lifelong learning in both country scenes.

The supervision of these intellectual works is followed by a research advisor (Figure 1). He/she, reserved modalities and complex differences among UW, Master's or PhD thesis involves a guided research from the specification of the proposal through the construction of final document. Consequently, the assignment of a research advisor might take in account the process of building strategies and contexts that would fulfill students' requirement, providing them with subsidies to acquire skills and abilities related to study management, information selection and organization, and knowledge construction (Mustaro et al., 2006b).

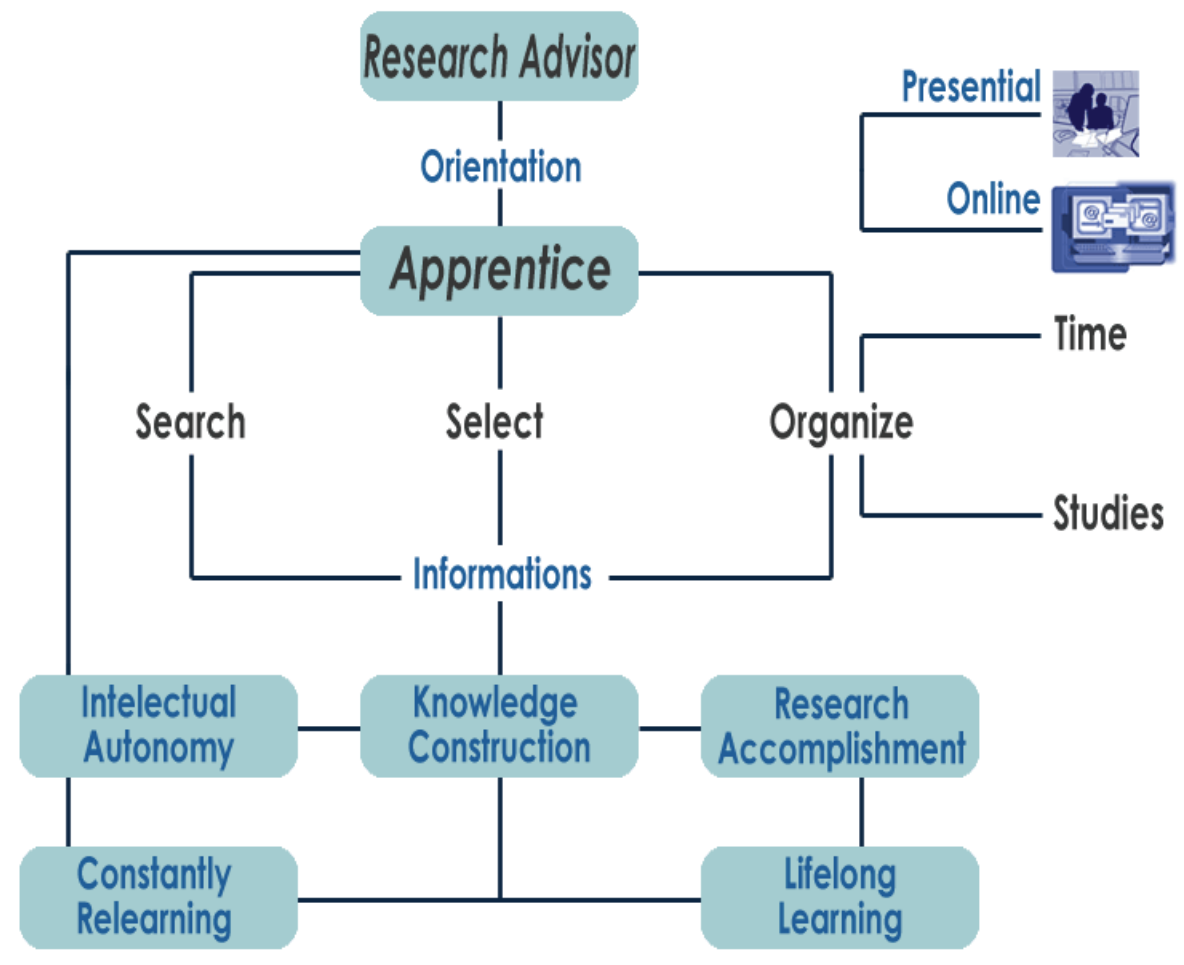

Figure 1 - Position of Research Advisor based and adapted from Mustaro et al. (2006b)

These elements can be explored in both ways, face-to-face or virtually; they result not only in the research accomplishment but also in intellectual autonomy for projects' construction and scientific reports (Saviani, 2002). From this point of view, nowadays, it can be considered that the orientation process is not related only to physical distance between the research advisor and the advisee anymore, but mainly to Internet access (Chassot, 2002). This eliminates the space-temporal barriers, and institutes a vehicle of direct interaction for communication. The use of technological tools also assists in documentation, configuration and tracking of history contacts, which helps the research progress follow-up.

This orientation proposal is related to a pedagogical model where the personalization of the learning process is prioritized as interaction possibilities in learning networks (Mustaro, 2006a) and virtual communities (Pallof \& Pratt, 1999). Moreover, this approach considers the needs and characteristics of "net generation" (Tapscott, 1998) - formed by people who present fluency in relation to digital media because they were born surrounded by technology such as television, video game and computers. According to this, net generation learners have abilities concerned to image visual interpretation and visual-spatial integration, as well as they usually learn better by inductive discovery. They are also able to quickly changing their attention, giving fast feedback to stimuli (Oblinger \& Oblinger, 2005). 
However, a bibliographical survey in journals, books, and electronic documents indicate that references focusing in the orientation process issue are scarce in literature, becoming a relevant topic for research.

To explore this scenario, the present article was organized in the following way: section Processes and Types of Orientation presents elements related to the conceptualization of orientation types and others related research elements; section Learning Approaches and Technological Tools refers to instructional design include in blended orientation proposal and supporting tools; section Case Study of Blended Orientation explain the methodology adopted throughout the research; section Results and Reflections about Experience makes use of collected data analysis and discusses the results obtained; finally, section Conclusions and Further Works presents conclusions pertinent to the case study and possibilities related to next steeps in this study area.

\section{Processes and Types of Orientation}

According to Chassot (2003), science constitutes a kind of language whose learning involves a scientific literacy. In this direction, he points out that science uses a specific language to explain phenomena and knowledge elaboration well-founded in methodological rules, what requires learning of specific codes inherent to this kind of communication. In a complementary way, the author emphasizes the relevance of this literacy for the development of people able to understand and to collaborate for the maintenance, transformation, and construction of a world where they live by means of scientific and technological elements.

It is also important to highlight that technological revolution caused repercussions in the writing forms, accelerating the writing process and language modification (Chassot, 2002). In this context, the access to Internet established a reduction factor of distances between advisor-advisee. Nevertheless, the study of orientation process related to the communication between these actors still is a research area few explored, especially from the point of view of technological use of tools that support this interaction (Lima \& Ferraz, 2006; Leite Filho, 2004).

Notwithstanding, to initiate a discussion about orientation process it is relevant to explore it from a conceptual approach. Bianchetti and Machado (2002) declared that "orientation means to characterize for the authorship". According to these authors, this procedure involves knowledge construction and development of a writing style. For this research advisor, by means of questionings and task definition to be concluded in determined periods, stimulates the student researcher to construct his principles in an independent mode and to articulate them in a way to elaborate a text in a scientific fashion.

To complement theoretical elements here presented, it is relevant to define autonomy from the pedagogical point of view. In this area, autonomy concerns to the individual capacity of assuming his/her own responsibility for the learning process instead of a passive position of information and knowledge receiver; such development requires experimentation (Freire, 1998). Lima (1973) suggested that autonomy involves some kind of prerequisites as liberty, reciprocity, objectivity, spontaneity, and group analysis, being defined as an "intellectual maturation process".

Another element in this context is critical thinking. Freire (1998) pointed that educational institution, as the center of systematic knowledge production, promotes experiences that allow creativity improvement. As a result, in scientific area it is necessary to let student gradually assume his/her role on reflection and autonomous work in research development.

Moreover, it can be said that orientation process is characterized as a workmanship activity. This occurs because, according to Freitas and Zawislak (2005), it is necessary to attempt against the elements as differences between students profiles, professors, affinity between research advisor and advisee, interest of both about the research subject, and availability of time for orientation. 
According to these authors, the item presented previously involve others variables as fast feedback in relation to research development, observance of stated periods, degree of guiding, devotion to scientific work and access to research advisor.

The accessibility to research advisor is a determining element to establish a relation advisoradvisee that makes possible to accomplish the goals and to finish the research. This factor can be extended significantly by means of online orientation. This involves, primordially, space and/or temporal apartness between advisor-advisee, use of digital technologies for synchronous and asynchronous communication, electronic forwarding of materials/references and text analysis and review.

\section{Learning Approaches and Technological Tools}

Dialog as element of humanist pedagogy proposals (Moore, 1993) can be adopted in blended orientation approach, because it institutes a constitutive space (face-to-face or even in virtual environments) of positive interaction where research advisor and advisee have the opportunity to solve problems together based on the tripod language, thought and action.

Moreover, from instructional design point of view, it is possible to establish an analogy between student-centered techniques (Pallof \& Pratt, 2004) and methodologies that can be used in online orientation processes. Consequently, the selection of tools must consider pedagogical functionality for development process of research and easiness of use.

In this direction, popular tools like email and instant messaging (IMs) can be used as primary tools for orientation process. The first one is characterized as textual/hypertextual asynchronous communication for exchanging messages, questionings, directions, documents, and so on, between advisor-advisee. In case of using free Web-base email services like GMail, for instance, which eliminates the need for a specific mail client, it is possible to check messages anytime, anywhere. Moreover, GMail-like message organization allows advisors and advisees to analyze the description of a specific subject, since it establishes a chaining of messages according to their heading, which contributed to a shallow analysis of learning rhythm and advances carried through by advisees.

On the other hand, IMs like MSN Messenger or ICQ, for example, are often hybrid tools (allowing synchronous and asynchronous communication) that provide message exchange between authorized people in a contact list. It is also possible to check users' status (what characterizes the degree of availability or absence for interaction). The advantages of IMs for educational purposes are limited by the inherent restriction of synchronous message exchanging only among preregistered people that are connected to the Internet in a certain moment. This resource, which also makes possible file exchange, allows groups to make spontaneous virtual meetings, where students interact with professors or colleagues.

In a complementary way, there are some resources that extend classical functionalities of text editors. Among the existing elements that can be used for technologically mediated revision process of academic text, an example of a tool that allows comments and tracking of changes is shown in Figure 2. The first one allows research advisor to add questionings, comments, notes about paragraphs/sentences structure, and even indications of the necessity of complementation, withdrawal of an excerpt, and displacement of this for another part of report or establishment of links between text parts. The second enables suggestion of alterations/corrections related to language in way to observe clarity, objectivity, and concision of scientific documents. 


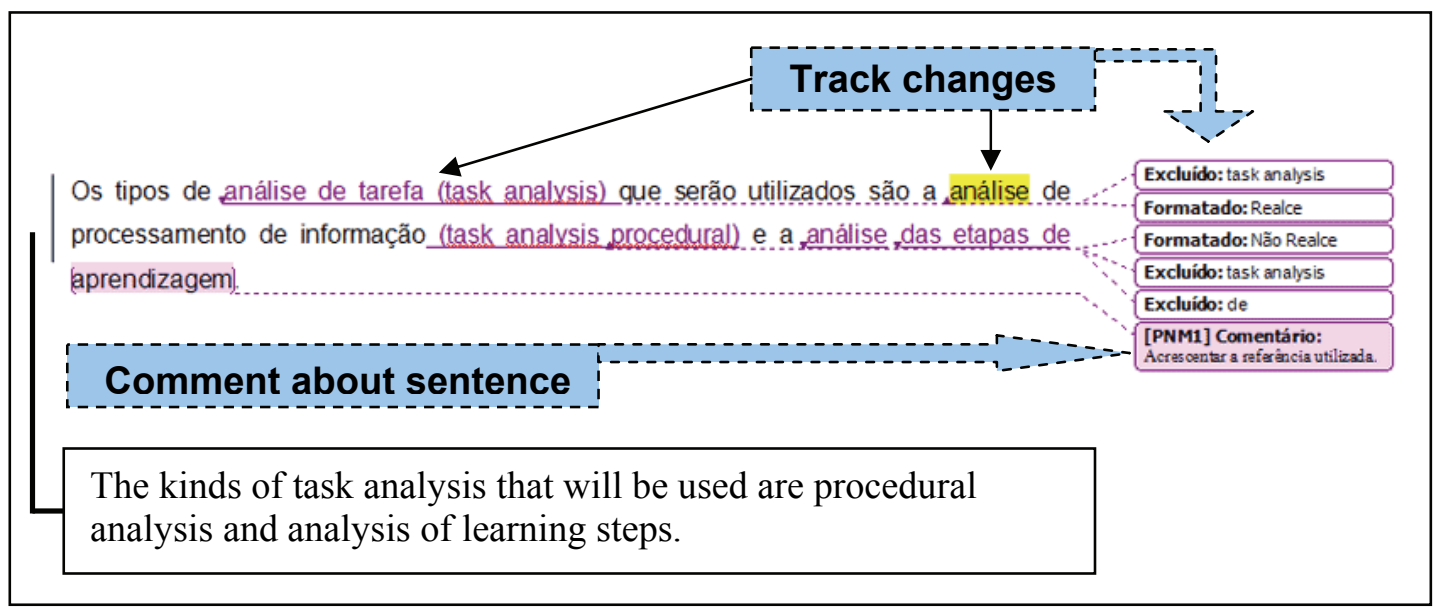

Figure 2 - Example of text review with comments and tracking of changes

Besides, two strategies related to orientation proposal were adopted in this paper: elaboration of mind maps and workshops. Mind maps (Buzan, 1974) can be used to graphically map a subject domain in a non-sequential way through the establishment of connections among words, icons and graphics by using different visual elements like colors, arrows, etc. In a pedagogical viewpoint, mind maps facilitate notation, data registration, and other kinds of elements that contribute for collaborative thought, planning and organization of ideas to write abstracts, reviews, and so on. In the special case of orientation process, mind maps allow the research advisor to visualize how student researcher articulates ideas and make links between texts, concepts, and theories. Furthermore, the use of freeware, open source or Web 2.0-based software permits forwarding digital maps to research advisor and comment this by synchronous or asynchronous way.

Workshops constitute biweekly or monthly face-to-face events taken along the semester, when student researchers and professors set up a research group to debate aspects related to scientific methodology, discussing certain characteristics of works in progress. Such activity helps to build a learning network that can be expanded by using a supporting virtual environment. Meetings were also designed to be a space where student researchers can make previous presentations of their works before formal presentation and evaluation.

This combination of face-to-face and online strategies articulates dialog and focus autonomy and creative development of student researchers.

\section{Blended Orientation: A Case Study}

Based on the concepts presented in previous sections, a qualitative research was thus accomplished. It involved the accompaniment of seven 22-29 year-old student researchers, whose four of them were enrolled in a Computer Science Undergraduate Course; one in an Information Systems Undergraduate Course; the other two attend a Master's in Electric Engineering. All of them were students at Mackenzie Presbyterian University, in São Paulo, Brazil. Therefore, the results presented in this article mention an observational participant case study (Bogdan \& Biklen, 1992) based on descriptive data and prioritization of interaction process of a specific group.

As complementary sources of data fetching, it were used the analysis of IMs logs and e-mails sent/received throughout the process, as well as the application of a survey prepared with open questions to analyze free expression of student researchers. Such survey was sent by email in order to establish an asynchronicity, which allowed interviewee to better reflect about the questions and answer them in a detailed, impartial way, emphasizing the each one's experience. After the 
examination of these documents, the material related to experience (presented in next section) was classified, organized, and analyzed.

From the point of view of which didactical strategies could be implemented with these advisees in face-to-face and online instances, it was reinforced, since the early beginning, that the choice of subjects should be associated to personal interests. It must be highlighted that in the beginning of orientation process, meetings with students had been also held in order to establish a work strategy, explaining which were the orientation expectations. Also, a work with students was performed (before the beginning of the formal orientation process) to establish the aspects that makes the difference between a research and a syllabus' work.

Throughout this preparation, some questions raised: which digital tools could be used during the research? how techniques related to scientific methodology could be applied to projects? and, which were the expectations, from the orientation point of view, related to the development of the investigative activity? All these questions included the discussion of different theoretical approaches and diversification of literary sources in order to establish a literature review.

Considering these prerogatives, an online attendance structure using common tools (to facilitate and motivate communication between research advisor and advisee) was developed. In this direction, it is possible to highlight the use of MSN Messenger as an instant messaging communication tool. This was adopted since it is the most used platform in this segment, counting with more than 240 million of users around the world, with 19,4 million of them living in Brazil (Comunicação Integrada, 2006).

During the orientation process, email and primary MSN Messenger (sometimes GTalk was used due to MSN Messenger unavailability) has been used for sending and receiving bibliographical references and text versions. Otherwise, emails and MSN Messenger had also been used, for instance, to supply feedback to young researchers that indicates the accomplishment of some task, or from research advisor who can place questions, answer questionings or even present elements that allow advisee to reflect about research.

The use of the MSN Messenger in writing activities also objectified that the students developed the capacity of written expression, especially scientific writing, therefore discussions also involved the text construction. Students, due to mediated communication, tried to express themselves in their best way in order to be understood. This is associated to the question of formalizing ideas, concepts, etc. through writing. Such activity demands reflection and construction of relationships among concepts.

Moreover, a simplified version of MindManager (Mindjet, 2006) called Mindman Personal or Freemind, an open source project (FreeMind - free mind mapping software, 2006) was adopted as a tool for developing mind maps. Such maps were discussed in both ways, face-to-face and online, helping to produce texts review, research design, and other types of documents related to scientific works (Figure 3). 

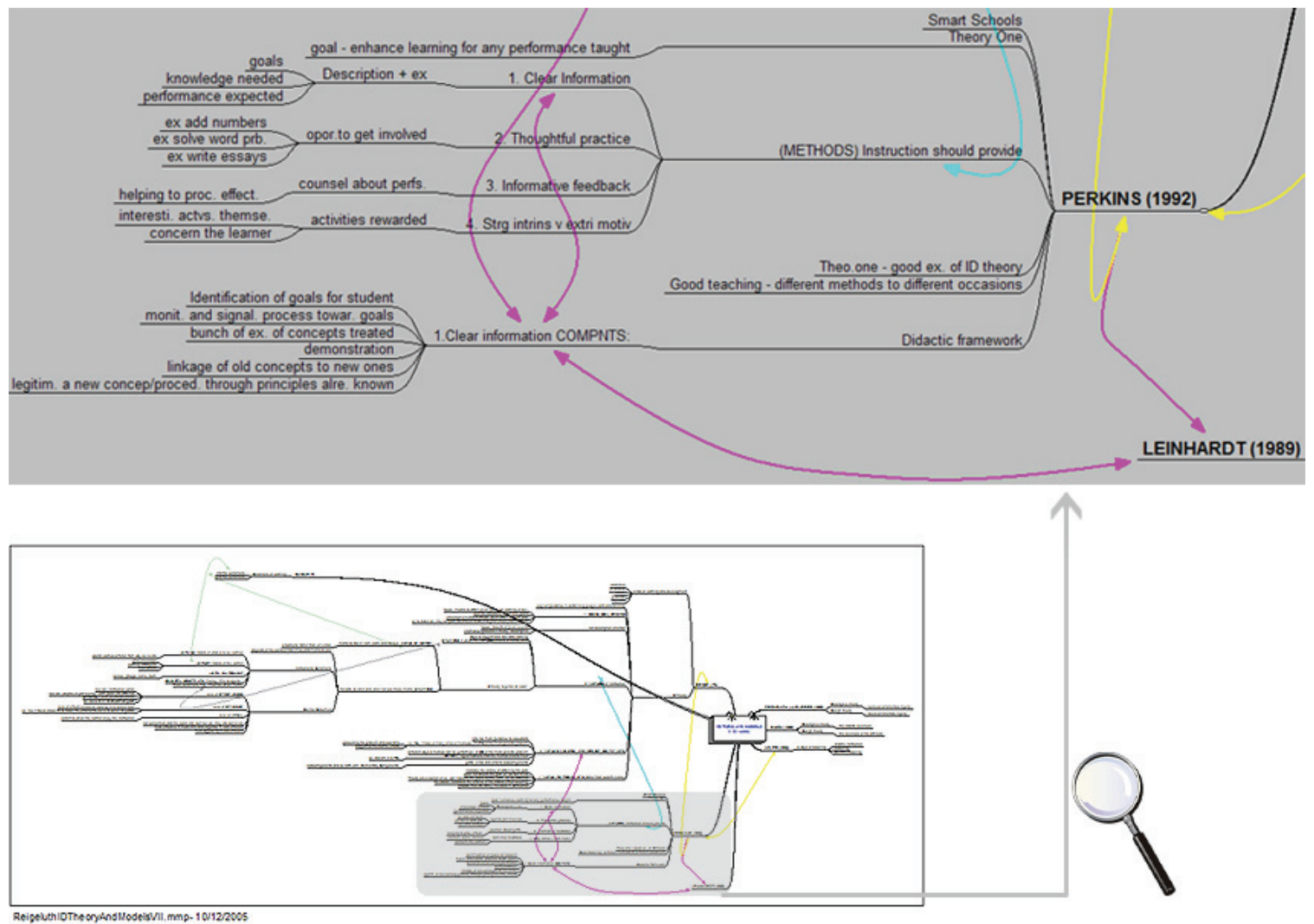

Figure 3 - Example of literature review mind map extract make with MindMan Personal

Finally, it fits here to stand out that, since the beginning of orientation process, we worked with text editors with support to comments and version changes in order to make possible to give students feedback with a maximum of two days delay (thus following the virtual netiquette).

\section{Results and Reflections about the Experience}

The group of students targeted by this experience, all of them characterized as belonging to net generation (Tapscott, 1998), presented one high degree of technological familiarity and massive use of technologies. It can be explained by the fact that the group was comprised by students associated to Math and technology-related areas. For instance, only one of them stated that his average daily time of computer usage was less than eight hours. This fact indeed facilitated the whole experience, since the use of technologies was present throughout the research.

In order to allow a contextualized analysis of blended orientation, a interview was made with the students after the process. The questions provided background to construct a referential frame related to theoretical-practical corpus of student researchers and the meaning of research concepts. The results of such interview were analyzed and are here presented.

Most of the interviewees placed that a scientific research looks for solutions to existing phenomena, as well as it targets the knowledge construction, which would collaborate for evolution of a certain knowledge area.

Related to researcher qualities, interviewees declared that several elements are involved on it, among them were pointed (in degree of importance) persistence, curiosity, interest for learning and the need for organization and methods. 
Besides, it was evidenced that success of subject choices and even the accomplishment of research had been, in a certain measure, linked to intrinsic motivation of student researchers. This learners' personal order interrelationship allowed a deeper involvement and engagement of them to research.

However, this element cannot be considered separately. Research advisor must stimulate written expression of advisee so that he/she could clearly contextualize the research question, explain the relevance of work and objectives definition in order to accomplish it. Therefore, they tried to work with scientific writing guided by suggestions and examples presented, which included the structure of text construction usually found in e-mails and in texts generated by revision resources of text editors (comments, track changes). It was observed that the use of mind maps contributes to express ideas and relations among concepts and also permits the organization of a logical chaining of parts included in research document.

It was observed, during the research period, that these instruments had facilitated the writing process, allowing a refinement of such process in a faster, dynamic way. It also must be pointed that students, after feedback reception, during the reading of the comments/suggestions, often immediately contacted research advisor through IMs (MSN Messenger or GTalk). This resource has iconic elements (emoticons) that complement literal communication, which facilitates interaction and made possible the reduction of interpretation errors due to the lack of non-verbal communication.

The use of IM for virtual contact with research advisor was still pointed by students as a relevant element throughout research accomplishment. Such resource collaborated, in a determinative way, along all process development with advisees. It is relevant to emphasize that MSN Messenger, due to its synchronicity, allowed the research advisor to promote, in an effective way, discussions, reflection and, in some cases, navigations through web pages. Tasks like collaborative changing of documents, like diagrams, was performed by MSN Messenger in a more efficient way than GTalk. However, it is relevant to highlight here that this implies, on the other hand, in a work overload for the accomplishment of online orientations, especially when a considerable number of advisees are developing research simultaneously.

Moreover, it is also possible to highlight that current web mail storage possibilities allowed the complete mobility of advisors and advisees. This allows advisors to perform reviews anywhere, besides keeping track of all messages and file that were exchanged along the orientation process.

The analysis pointed an interesting fact: face-to-face meetings were scheduled only when necessary, and these meetings were often productive, since most of the time was spent to clarify doubts and to discuss pertinent questions related to scientific work. Nevertheless, the pedagogical proposal instituted for face-to-face meetings (orientation meetings and research workshops) was structured in order to allow students to exchange experiences, knowledge, references, doubts, distresses, etc. which naturally established a collaborative social network among them.

However, two of the interviewees, because of their professional agenda, did not have availability to attend face-to-face meetings. In this case, their orientation was performed nearly always and exclusively online. Nevertheless, both had declared that it did not affect the process nor created any kind of distance between advisor-advisee. In this direction, the experience was still considered positive considering the tools used for online orientation.

The students had been unanimous in declaring that spontaneous online meetings and scheduled online meetings collaborate for research development. In relation to the differences between them, students stated that spontaneous meetings were often dedicated to doubt solving, to exchange or request materials and to share questions pertinent to the research. On the other hand, scheduled meetings had a clear purpose, according to its objective. In this way, students pointed 
that such meetings were meant to promote discussions related to textual elements elaborated along research or even brand new ideas that could collaborate with reflection throughout the investigation process.

However, it is possible to highlight that one of the interviewees presented a complementary aspect in relation to scheduled meeting: the need of a better involvement and the lack of time availability to deal with a subject in depth. Finally, other student stated that he did not perceive difference between these two modalities of meeting, but that both accelerated and collaborated to the conclusion of the research. These variations can be related to time and request frequency of scheduled and spontaneous meetings, even though the observation throughout process indicated that second type had occurred significantly more.

At last, it was questioned if there should be programs or specific platforms to assist orientation processes. Six students had been favorable to the development of such tools, and they indicated some integration requirements of the following elements: communication tools; scientific texts repository with support for comments and timecards; a resource for setting and organizing research bibliography; an area for controlling versioning and simultaneous document edition; a calendar for events and other information related to research; a message board; a space for sharing doubts; and a videoconference tool.

A complementary consequence of the blended methodological approach here presented was that the joint work with these seven interviewed student researchers resulted in some scientific publications, totalizing eight full papers and three abstracts in international and national conferences, as well as an honor mention in scientific initiation symposium.

\section{Conclusions and Further Work}

It is possible to observe that almost all literature related to the orientation process focus mainly in procedures and face-to-face interaction when developing Master's and $\mathrm{PhD}$ thesis, often in $\mathrm{Hu}-$ man Sciences area. This leads to an increasing necessity of researches related to orientation instances in hard sciences especially in technology-related fields. A special attention must be paid to those studies that consider technologic tools for communication among advisor-advisee and research group and for organization of materials related to scientific work. Such tools could also take advantage of open source virtual learning environments (VLE) for development of a orientation module that supports necessities previously presented.

In relation to face-to-face and online orientation processes, it was possible to conclude that these are in fact complementary to each other, and together institute the basis for blended orientation.

Face-to-face meetings had been characterized as punctual, focused reunions that address more abstract discussions. From the point of view of this research, it can also be figured out that communicational mediation implemented by some widely used, freeware communication tools contributed to solve important questions related to students' research in a more agile form. In the same way, them helped students to acquire a scientific literacy, which culminated in a better autonomy of student researchers and a noticeable maturity related to inquirer position. It was possible to create an environment for constant discussion, which promoted better proximity and interlocution among advisor-advisee, resulting in publication of scientific articles and participation in events.

However, these elements and results are pertinent to this present study and they cannot be generalized. Nevertheless, they indicates some paths for new explorations and researches that could make possible to establish pedagogical proposals for use and/or development of computermediated tools that would collaborate in orientation processes of scientific works in contemporary era. 
Finally, it must be pointed out that this methodology also implies a significant availability of research advisor's time, which can result in a work overload due to the flow and urgency of text revisions, mainly near common deadlines. This requires new theoretical incursions to institute mechanisms that can equalize this question.

\section{Acknowledgments}

The author would like to thank Lia Carrari Rodrigues, Marcelo Adade Gonçalves, Patric Ferreira da Silva, Leandro Pupo Natale, Vagner Figuêredo de Santana, Hamilton de Matos, and Jonas Gentina for their collaboration to accomplish this research.

\section{References}

Bogdan, R. \& Biklen, S. K. (1992). Chapter one. Foundations of qualitative research in education: An introduction; Chapter two. Research design - Case studies. In Qualitative research for education: An introduction to theory and methods (2nd ed.) (pp. 1-57; pp. 62-69). Boston: Allyn and Bacon.

Bianchetti, L. \& Machado, A. M. N. (org.). (2002). A bússola do escrever: desafios e estratégias na orientação de teses e dissertações. [The compass of writing: challenges and strategies in orientation of thesis and dissertations]. Florianópolis/São Paulo: Editora da UFSC/Cortez.

Buzan, T. (1974). Use your head. London: BBC Books.

Chassot, A. (2003). Alfabetização científica: uma possibilidade para a inclusão social. [Scientific literacy: a possibility for social inclusion]. Revista Brasileira de Educação [Brazilian Journal of Education], 22, 89-100, jan./abr.

Chassot, A. (2002). Orientação virtual: uma nova realidade. [Virtual Orientation: a new reality]. In L. Bianchetti \& A. M. N. Machado (Eds..), A bússola do escrever: desafios e estratégias na orientação de teses e dissertações. [The compass of writing: challenges and strategies in orientation of thesis and dissertations] (pp. 135-163). Florianópolis/São Paulo: Editora da UFSC/Cortez.

Comunicação integrada. [Integrated communication] Windows Live Spaces traz rede social. Retrieved September 10, 2006 from http://www.s2.com.br/scripts/release print.asp?clienteID=362\&releaseID= $\underline{19159}$

Freitas, H. R. \& Zawislak, P. A. (2005). Como deve ser, afinal, o desenvolvimento do processo de mestrado em administração? [How it must be, after all, the development of master process in administration?]. Retrieved August 15, 2005 from http://read.adm.ufrgs.br/read02/artigo/freitas.html

FreeMind - Free mind mapping software. (18 Nov 2006). Retrieved November 20, 2006 from http://freemind.sourceforge.net/wiki/index.php/Main_Page

Freire, P. (1998). Pedagogy of freedom: Ethics, democracy and civic courage. New York: Rowman \& Littlefield Publishers Inc.

Hussar, W. J. (2005) Projections of education statistics for 2014 (NCES 2005-074). U.S. Department of Education, National Center for Education Statistics (NCES). Washington, DC: U.S. Government Printing Office. Retrieved June 28, 2006 from http://nces.ed.gov/pubs2005/2005074.pdf

Leite Filho, G. A. (2004). A relação orientador-orientando e suas influências no processo de elaboração de teses e dissertações dos programas de pós-graduação em Contabilidade da cidade de São Paulo [The advisor-advisee relation and their influences in the elaboration process of master and doctor thesis in post-graduation programs of Accounting in the City of São Paulo], Master Thesis, Universidade de São Paulo.

Lévy, P. (1997). Collective intelligence: Mankind's emerging world in cyberspace. New York: Plenum.

Lévy, P. (2001). Cyberculture. Minneapolis: University of Minnesota Press.

Lima, L. de O. (1973) Treinamento em dinâmica de grupo. No lar. Na empresa. Na escola. [Training in group dynamic. At home. In company. At school.] (4th ed.), Petrópolis, Rio de Janeiro: Vozes. 
Lima, T. C. B. de \& Ferraz, S. F. de S. (2006). Supervising junior researchers in virtual environments based on the perspective of collaborative learning, Proceedings of $22^{\text {nd }}$ ICDE World Conference on Distance Education, Rio de Janeiro, 1-11.

MindManager (2006). Mindjet. Retrieved 12 August, 2006 from http://www.mindjet.com/us/

Moore, M. G. (1993). Theory of transactional distance. In D. Keegan (Ed.) Theoretical principles of distance education. New York: Routledge.

Mustaro, P. N. (2006a). An interdisciplinary approach to the development of a learning networks in virtual environments. Proceedings of $22^{\text {nd }}$ ICDE World Conference on Distance Education, Rio de Janeiro, 111.

Mustaro, P. N., Stump, S. M. D., \& Omar, N. (2006b) Methodology for development and application of interactive and simulation tools in virtual environments for science and technology education. Proceedings of the 12th IOSTE Symposium. (pp. 697-703) Penang : Zillion Circle (M) Sdn. Bhd.

Oblinger, D. G. \& Oblinger, J. L. (Eds.) (2005). Educating the Net Generation. EDUCAUSE. Retrieved January 10, 2006 from http://www.educause.edu/ir/library/pdf/pub7101.pdf

Palloff, R. \& Pratt, K. (1999). Building learning communities in cyberspace. San Francisco: Josey-Bass Publishers.

Palloff, R. \& Pratt, K. (2003). The virtual student: A profile and guide to working with online learners. San Francisco: Jossey-Bass.

Plano Nacional de Pós-Graduação (PNPG) - 2005 - 2010. Resumo Executivo. [National Plan of PostGraduation (NPPG) - 2005 - 2010. Executive Sumary]. (2004, December) Brasília. Retrieved June 15, 2006 from http://www.capes.gov.br/rbpg/portal/conteudo/185 198 plano nacional posgraduacao 2205 2010.pdf

Saviani, D. (2002). A pós-graduação em Educação no Brasil: pensando o problema da orientação. [The Education Post-Graduation in Brazil: thinking about the orientation problem]. In L. Bianchetti \& A. M. N. Machado (Eds.). A bússola do escrever: desafios e estratégias na orientação de teses e dissertações. [The compass of writing: challenges and strategies in orientation of thesis and dissertations] (pp. 135-163). Florianópolis/São Paulo: Editora da UFSC/Cortez.

Tapscott, D. (1998). Growing up digital: the rise of the net generation. New York: McGraw-Hill.

\section{Biography}

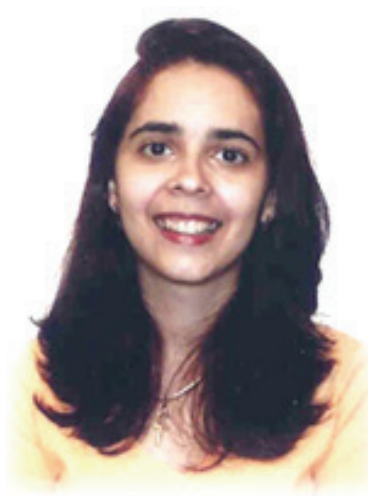

Pollyana Notargiacomo Mustaro obtained her PhD in Education (São Paulo University, 2003), being specialized on Internet hackers' Knowledge Building Process. Nowadays, she is a professor at Mackenzie Presbyterian University. Her research areas include Learning Objects Theory, Learning Styles, Instructional Design, Distance Learning and Hypertext Theory. 